\title{
Climate change, power, and vulnerabilities in the Peruvian Highlands
}

\author{
Anna Marjaana Heikkinen ${ }^{1}[$ \\ Received: 28 September 2020 / Accepted: 2 August 2021 \\ (C) The Author(s) 2021, corrected publication 2021
}

\begin{abstract}
The intensifying impacts of climate change pose a serious global threat, particularly for rural populations whose livelihoods are closely tied to natural resources. Yet there is a lack of critical understanding of how asymmetric power dynamics shape the vulnerabilities of such populations under climate change. This article examines the interrelations between smallholders' climate-related vulnerability experiences and power relations across multiple scales of climate adaptation in the Peruvian Andes, a region susceptible to increasing climatic threats. The analysis draws on a case study conducted in the Mantaro River Valley in Central Peru using qualitative methods: open-ended interviews, participant observation, and document analysis. Findings of the study show that in the context of climate change, the production of vulnerabilities has much to do with larger socio-political structures in which protection of the highland farmers is not prioritized. The impact of the uneven scalar power dynamics in climate adaptation and other overlapping fields of policy have created uneven terms of adaptation among smallholders. This has created marginalization, conflicts, and deepened smallholders' vulnerabilities under climate change. I argue that to reach a better understanding of the multidimensionality of vulnerabilities, more detailed attention must be paid to place-based climate experiences within context-specific, socio-political processes, and to the ways these are shaped by unequal power relations across multiple scales.
\end{abstract}

Keywords Vulnerability $\cdot$ Climate change $\cdot$ Power relations $\cdot$ Smallholder agriculture $\cdot$ Andes $\cdot$ Peru

\section{Introduction}

It is increasingly acknowledged that the impacts of climate change will not affect everyone equally. Marginalized rural populations that depend on natural resources for their livelihoods are at particular risk (IPCC 2014). Nevertheless, a growing number of scholars have problematized the approach which sees vulnerabilities as a simple outcome of climatic variability. These argue that vulnerabilities are rather produced by asymmetric socio-political power relations that shape unequal distribution of the risks and benefits under climate change (Nightingale 2017; Ribot 2010, 2014; Taylor 2013, 2015). This article analyzes the interrelations of climate change, power, and the (re)production of vulnerabilities among smallholder farmers in the Peruvian

Communicated by Debbie Ley.

Anna Marjaana Heikkinen

anna.heikkinen@helsinki.fi

1 Global Development Studies, University of Helsinki, Snellmanninkatu 14 C, 00014 Helsinki, Finland
Highlands. The region consists of diverse ecosystems, including tropical glaciers, that are highly sensitive to the impacts of climate change (Mark et al. 2017). In recent decades, weather extremes such as droughts, frosts, and intense rains have increased (Anderson et al. 2011), and rising temperatures have accelerated the melting of the Andean glaciers (Rabatel et al. 2013; Vuille et al. 2018). This poses a serious risk to highland smallholder livelihoods, which depend on rains and glacier meltwater for irrigation (Perez et al. 2010). Moreover, the historical marginalization (Crabtree 2002) and Peru's neoliberal regime over the past decades that have prioritized large-scale agribusinesses, have further weakened smallholders' opportunities to cope with climate risks (Lennox and Gowdy 2014).

Studies from diverse mountainous regions in the Global South illustrate that uneven governance structures exacerbate marginalized communities' exposure to climate threats (Holler 2014; Montaña et al. 2016). In Peru, Zimmerer et al. (2018) show how agricultural policies that promote cheap industrial foods made Indigenous highland smallholders' climate adaptation attempts for sustainable farming practices much more difficult. Peru's highland populations' 
vulnerability to climate change has also been deepened by uneven water governance (Lynch 2012). In recent decades, both natural and social science research on the Andes have emphasized the need to pay more attention to socio-political dimensions in vulnerability analyses (Bury et al. 2011; Drenkhan et al. 2015; Mark et al. 2017; McDowell and Hess 2012; Rhoades et al. 2008). Recent works have also increasingly drawn attention to power relations within the multifaceted socio-ecological and political-economic dynamics shaping climate-related vulnerabilities (Lynch 2018; Paerregaard 2017; Stensrud 2019).

This article contributes to this body of research by examining the scalar power dynamics in Peru's climate adaptation, and how these compound highland smallholders' vulnerabilities under climate change. Using the case of the Mantaro River Valley, I analyze how farmers experience climatic changes, and how the vulnerability perceptions and outcomes interrelate to Peru's climate adaptation efforts. The study takes a political ecology of vulnerability approach to address how disproportionate multi-scalar political-economic and social relations compound vulnerabilities to climate change (Ribot 2011, 2014). Given the complex nature of such processes, the analysis focuses on how power and vulnerability are intertwined across diverse scales and manifested in local landscapes transformed by climate change (Taylor 2013, 2015). Doing so, this study seeks to provide empirical and theoretical insights into interconnections between power and vulnerabilities among marginalized rural populations faced with climate change.

The following section introduces the political ecology of vulnerability framework. The third section describes the study site and research methods. This is followed by analysis of smallholders' vulnerability experiences and how Peru's climate policies respond to context-specific vulnerabilities in the highlands. The fifth section examines the influences of uneven power dynamics in wider field of policy and scalar configurations in (re)producing vulnerabilities. The article concludes with a discussion of the underlying processes shaping highland farmers' vulnerabilities to climate change, and how these could be managed in more equitable ways.

\section{Political ecology of vulnerability and power}

Much of the earlier research on climate vulnerability has focused on biophysical hazards. However, political ecology-oriented scholars have problematized this approach for dismissing the multiple socio-political processes mediating vulnerability to environmental change (Basset and Fogelman 2013; Eriksen et al. 2015; Nightingale 2017; Ribot 2014; Taylor 2015). Such critical works on vulnerability emphasize that people do not become vulnerable to climatic stresses simply because they are poor or lack capacities.
Rather, they call for attention to the subordinating politicaleconomic conditions and forms of governance producing vulnerabilities prior to climate threats (Faye and Ribot 2017; Lynch 2012). Recent works have addressed how power relations embedded in resource access and representation (Ribot 2014), climate discourses (Perreault 2020), and place-specific histories (Turner 2016) shape pre-conditions of vulnerabilities. However, there is still a need to give greater attention to the ways scalar dynamics of power impact the experiences and responses of place-based climate stresses (Goldman et al. 2018; Ribot 2014), which is the focus of this article.

In this study, vulnerability is understood as a dynamic condition, driven by multifaceted forces within changing political-economic, social, and environmental processes across diverse scales (Marino and Ribot 2012; Nagoda and Nightingale 2017). The analysis draws inspiration from Faye and Ribot (2017: 2) who emphasize that vulnerabilities to climatic threats are "not about the 'capacities' of individuals, but merely the ways they are deprived of assets - through denied access to resources, markets and government." According to Faye and Ribot (2017), mainstream climate adaptation thinking, wherein vulnerabilities are framed as the shortcomings of an individual or a community, downplays the role of historically rooted societal structures in creating such conditions. As Forsyth also (2014) argues, before taking adaptation action one must first ask: why climatic threats become a risk for certain people and places in the first place. Without a deep understanding of the underlying drivers of vulnerabilities, including multi-scalar politicaleconomic processes, adaptation efforts risk remaining shallow (Ribot 2010).

This study thus seeks to be attentive to how scalar processes of power shape experiences and responses to climaterelated vulnerabilities (Ribot 2014). Following Moore (2008: 212), such processes are defined as the "scalar practices of social actors," meaning that fixed geographical scales are not treated as predetermined categories. Instead, the scalar categories are considered as fluid outcomes of overlapping social and political efforts through which the scales are produced and contested within and beyond a specific place (Sayre 2015; Nygren, 2021). This also applies to analysis of power dynamics, examined as crosscutting networks of hierarchical social relations that shape people's abilities to counter climate stresses through decision-making processes within and across the scales (Neumann, 2009). As Nygren (2021) argues, relational approach to scalar dynamics allows a more nuanced examination on how power relations and production of environmental vulnerabilities merge across scales. Drawing on these ideas, my analytical focus is on the ways vulnerabilities are (re)produced through different actors' and institutions' efforts to mold the scalar configurations (Swyngedouw 2004) through the distribution of power 
in access to resources and markets, and representation in climate adaptation (Faye and Ribot 2017). Moreover, the analysis considers how multi-scalar power dynamics in climate discourses shape peoples' vulnerability perceptions and experiences (Goldman et al. 2018).

Climate decisions that impact the everyday realities of marginalized communities are made from global treaties to local institutions (Ribot 2010). Therefore, analyzing the links between power and vulnerability within the scalar dynamics approach enables to disentangle who has a say and whose interests are present in climate adaptation policies across diverse moments of decision-making (MacKinnon 2011). Oftentimes adaptation practices are determined by powerful actors who rely upon technocratic approaches and predetermined indicators of vulnerability (Yates 2014). At worst, dominant technocratic climate discourses are further interpreted and used by local political leaders in ways that reinforce existing vulnerabilities (Artur and Hilhorst 2012). As Yates (2012) shows in his work on livelihood adaptation in rural Nepal, vulnerability categories defined by global actors became reconstructed in local spaces to drive selective adaptation practices that served the interests of powerful local actors. It is therefore necessary to consider not only the impacts of global climate decision-making on local vulnerabilities but also how local and regional institutions mutually (re)shape people's opportunities to cope with climate risks (Agarwal 2010).

Besides powerful techno-political arrangements, vulnerabilities can also be created and maintained through less visible acts. Here, power is not only about what is included in political agendas, but a practice whereby "some issues are organized into politics while others are organized out" (Lukes 2005: 20). In this sense, dominant actors apply power to control decision-making through informal channels to bypass or preclude the interests of marginalized people. In climate change adaptation, such "invisible" marginalization can occur through uneven power relations in policies beyond climate adaptation (O'Brien et al. 2008). For example, studies from the Peruvian Highlands suggest that Peru's neoliberal agri-policies - supporting monocultivation - have impaired agroecological farming practices (Zimmerer et al. 2018) which could help smallholders to mitigate climate threats (Lennox 2015).

More detailed attention needs thus to be paid to how climate-related vulnerabilities in a specific socio-economic context are shaped by power embedded in history, policies, and markets across multiple scales. Although many of these processes characterize marginalized rural environments in the Global South, I argue that responses to vulnerabilities must be built upon a better understanding of place-specific dynamics (Sietz 2014; Walsh-Dilley 2020) and their relation to scalar configurations (Swyngedouw 2004). In what follows, I analyze how diverse multi-scalar power relations simultaneously shape and produce vulnerabilities among, across and within a specific place through the case of the Mantaro River Valley of Peru.

\section{Study site and methods}

This study draws on field research I conducted in the Mantaro River valley between February and July 2019. The valley is located in the Central Highlands of Peru, ranging from 3100 to over $4200 \mathrm{~m}$ in altitude. Agriculture is the principle source of income for $40 \%$ of the valley's population (INEI 2019) of whom most are smallholders (CIIFEN 2018). The region has also an important role in maintaining food security in nearby cities and in Peru's capital, Lima (Vergara et al. 2011). In the lower parts of the valley, the farmers cultivate diverse food crops: potatoes, several corn varieties (maíz choclo, duro, and amiláceo), beans, barley, and olluco (DRA Junín 2019; MINAGRI 2018). At higher altitudes, crops are complemented by livestock and dairy production (IGP 2012).

As a part of the Andean biodiverse mountain range, the Mantaro Valley is characterized by high inter-annual climatic variability. Nevertheless, in recent decades, the climate patterns have been changing. Historical climate studies from the valley show that between 1965 and 2014 there was a notable decrease in rainfall, while extreme temperatures occurred more frequently (CIIFEN 2018). Climate scientists also warn that the risk of droughts, frosts (Trasmonte et al. 2008), and volatile rain patterns is increasing (Wongchuig et al. 2018). Due to the overall rise in temperatures, the largest glacier of the region, Huaytapallana, has lost over $68 \%$ of its glacial area $\left(46.63 \mathrm{~km}^{2}\right)$ since the $1960 \mathrm{~s}$ (INAIGEM 2017). Its accelerated melting poses a serious threat for future water availability in the region as it provides an important water supply for many farmers in the valley and for the 500,000 inhabitants of the region's largest city, Huancayo (Vergara et al. 2011).

Moreover, smallholder farming is at particular risk under predictions of intensifying climatic changes due to its dependence on rains. The farming activities in the valley take place in approximately 340,000 hectares of agricultural land. About $71 \%$ of this farming land is rain-fed, while only $29 \%$ is connected to irrigation (CIIFEN 2018). In recent decades, many farmers have experienced harvest losses due to unexpected climate extremes. Between 1995 and 2010, the agricultural campaign reports of the Junín department (the administrative entity of the Mantaro River valley), registered 


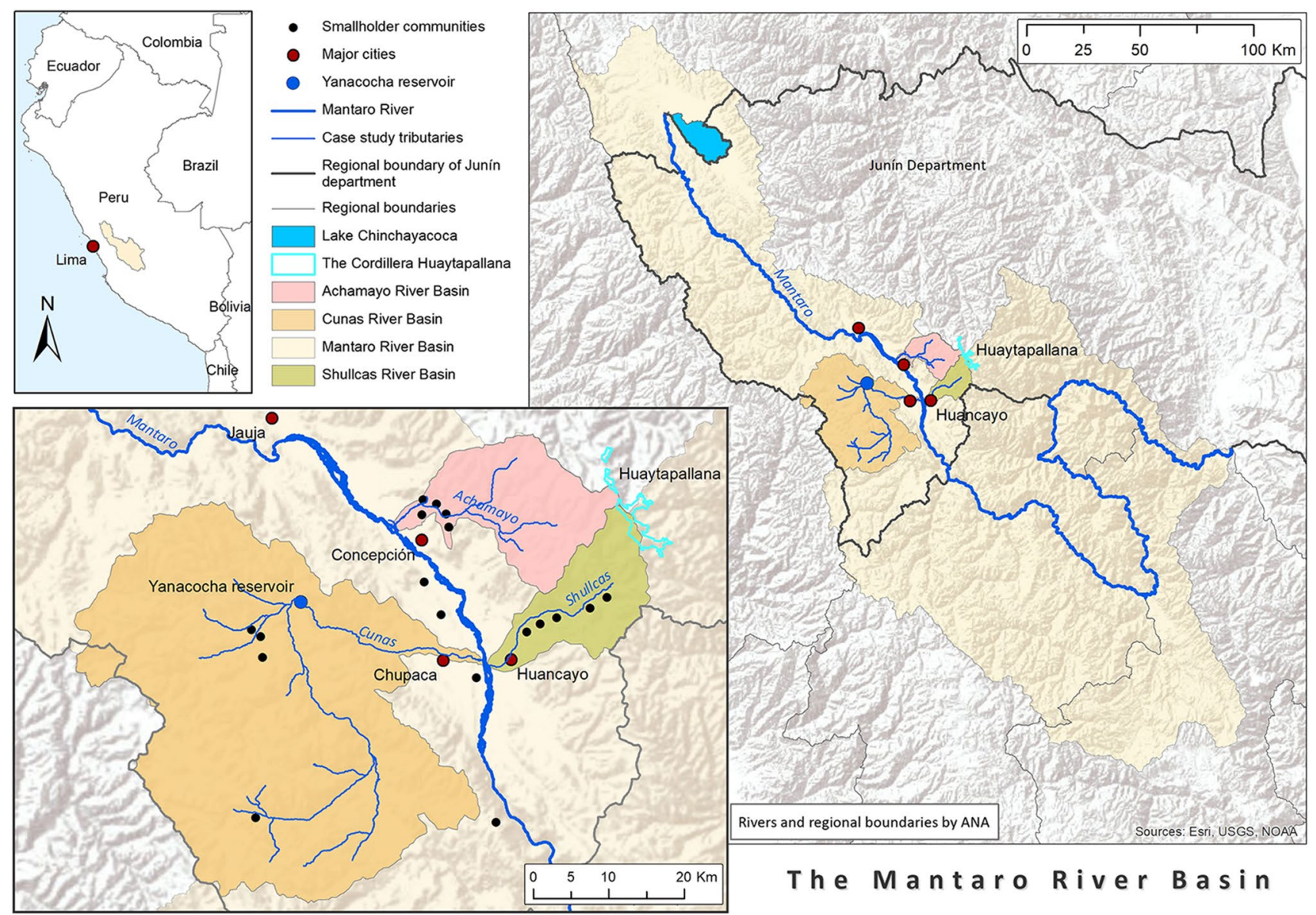

Fig. 1 Map of the Mantaro River basin and the case study tributary basins with locations of the smallholder communities. Prepared by Noora Rämö based on sources of ANA (2010)

14 cases of extensive agricultural damage, caused by climate anomalies. In 2006, severe frosts destroyed 14,400 ha of cultivated land, causing losses of 27 million Peruvian soles (IGP 2012). Yet there has been little political engagement in climate risk prevention in the valley's smallholder communities (IGP 2012).

The region was selected as a case study site due to the importance of smallholder farming, its sensitivity to climatic risks, and few studies addressing smallholders' climate-related vulnerabilities (CIIFEN 2018; IGP 2012). To capture the dynamics between power and vulnerabilities in the valley, I focused on smallholder communities located in three tributary basins: the Achamayo River, the Cunas River, and the Shullcas River. Before the fieldwork, I reviewed sitespecific literature and media reports to guide the methodological and field research design. Local newspaper articles, for instance, hinted that in recent years, tensions between state officials and smallholders had increased due to disagreements over water and agricultural management (Correo 2017; RPP 2018).
This study draws on qualitative methods, including semistructured interviews, participant observation, and content analysis of key policy documents related to climate adaptation. In all, I interviewed 60 small cultivators and livestock producers living along the three tributary basins. The interviews were constructed in thematic sections focusing on experiences of climatic, environmental, and livelihood changes. Moreover, I conducted over 20 interviews with state officials and other actors engaged in climate and agricultural policies at diverse governmental levels. These included representatives of the Ministry of Agriculture and Irrigation (MINAGRI), Ministry of Environment (MINAM), the regional government of Junín, water authorities, and local irrigation organizations among others. The interviews were recorded (some of the smallholders preferred not to be recorded, which was respected), transcribed, and thematically coded. During fieldwork, I also attended numerous meetings related to agricultural and environmental management, to gain a better grasp of the power relations between diverse actors engaged in climate adaptation (Fig. 1). 


\section{Smallholders' vulnerability experiences}

This research draws on the premise that vulnerability is not only a question of exposure to climatic risks, but also influenced by complex socio-political processes across multiple scales (Ribot 2010). My analysis pays specific attention to local perceptions of climatic changes, their effects on livelihoods, and to the ways state policies and access to markets at diverse scales shape these experiences. Like Gagné et al. (2014), I show that vulnerabilities are neither only a question of lost livelihoods but can have deep cultural implications for those observing the deprivation of the landscapes they inhabit.

The climate of the Peruvian Highlands has typically been characterized by marked shifts between rainy and dry periods. Usually it rains regularly between December and April whereas between May and November rain is rare. For centuries, Andean farmers have lived, sowed, and harvested following these seasonal patterns. Despite the distinct rain periods, the presence of the mountain range causes occasionally rapid shifts in weather. As highland smallholders' livelihoods are closely tied to the local agro-ecologies, people are used to managing and adapting to climatic variation. Yet the farmers I interviewed had observed that the division between rainy and dry periods was becoming blurred and weather events more extreme. This presented them with new challenges, as it had become more difficult to anticipate the right timing for sowing and harvesting. In many parts of the valley, unexpected weather events were also causing increasing yield losses.

In 2018 , the valley was hit by a wave of severe frosts, resulting in damage to over 40,000 ha of cultivated land (CONVEAGRO 2018). Corn and potatoes - the main crops cultivated by smallholders - were most affected. Many farmers lost a great proportion of their investment and income for the whole year. In response, MINAGRI distributed a 1-1 bottle of fertilizer per each lost hectare to the farmers - aid that was supposed to recompensate for harvest losses. When I asked local farmers about this, many burst into laughter. They considered that the aid was not only ridiculous, but also deeply disconnected from what was needed to re-establish the damaged fields. Sitting on the edge of her corn field, local farmer María Elena ${ }^{1}$ described her feelings to me:

What the central government was offering us was not something I would call help - one liter of that fertilizer is not enough even for half a hectare. When the frosts hit us, the losses are immense...the frost just burns

\footnotetext{
${ }_{1}$ Pseudonyms are used for all the interviewees to guarantee anonymity and confidentiality.
}

all the chacras. Now people are trying to re-work the land and others have used that fertilizer hoping to save their maicitos (little corns) but what I can see - it is all rotten and gone. The only thing we can do is to start all over again, but it will be difficult as the corn should already be blossoming. (May 16, 2019)

Similar stories about the government agencies' weak support in mitigating or recovering from climate extremes came up in several discussions with the farmers. There were some initiatives to prevent yield damages. One of them were textmessage alerts on climate anomalies and climate-adjusted farming calendars developed by the National Meteorology and Hydrological Service of Peru (SENAMHI). However, many farmers considered that these tools were not useful for managing the challenges they encountered. In their study, Orlove et al. (2011) discuss the complex, historically rooted dynamics of access to weather forecasts across Latin America. They show that, rather than governmental institutions, semistatal or nongovernmental "intermediate organizations" play the major role in disseminating climate information in specific regions and sectors like farming and fisheries. Common to these organizations is that they have worked for decades to accumulate regional knowledge and build relations within their sector. The farmers I interviewed did not mention any organization having a clear position as an intermediator in climate issues. However, farmers' distrust of SENAMHI's climate mitigation attempts might reflect a lack of such historically established trust relations and context-specific knowledge that Orlove et al. (2011) describe in their study.

In the absence of state support, many smallholders were developing their own strategies to counter climate anomalies. In the lower and middle valley, farmers, who focused on crop cultivation and had access to irrigation canals, were increasing irrigation to protect the fields against droughts and frosts. As extensive drought periods affected the water supply, obtaining enough water was sometimes challenging, as Juan Varillas, a smallholder in the Cunas River basin explained:

In the summers, the rains are no longer sufficient, so we must irrigate more to keep the land humid. What often happens though, is that the land dries in front of our eyes and so do the rivers and canals... and they are the only sources of water we have. (April 2, 2019)

These uncertainties had led many smallholders to shift from crop cultivation to guinea pig farming which was less sensitive to climatic variations and shortages of water. Even those who did not farm guinea pigs told that it had become more convenient to grow less water-thirsty pasture for those who did. Food crops were increasingly grown only for subsistence. The smallholders in the upper 
highlands were using similar strategies. As irrigation depends on rain in the higher altitudes, they had decreased crop cultivation to focus on meat and dairy. The farmers considered that livestock production was more appropriate as it was less susceptible to climate extremes.

Besides climatic risks, the farmers were concerned about the poor conditions of their farming land. According to them, it had become less fertile and "tired." When I asked, what had caused the deterioration, many answered that the valley's farmers did not take care of the land as their ancestors had. Andean smallholder agriculture has traditionally been based on diversified farming practices, such as pre-determined rotation systems, to anticipate environmental risks and crop losses (Velásquez-Milla et al. 2011; Zimmerer 1991). Now many farmers had abandoned such practices under increasing pressure to engage in commercialized agricultural production. As the soil had become less nutrient-rich, the farmers said that they had to apply more fertilizers to achieve better yields. Moreover, plant disease and insects had proliferated and tackling them required increasing use of pesticides. Protecting the fields from plague, reduced nutrients, and climate extremes meant increased investments without a guarantee of successful yields or income. As smallholder Walter Aquino ironically noted during our conversation: "Agriculture has become a risky business in our valley."

Their weak positioning vis-à-vis the agricultural markets did not help the farmers to overcome these challenges. The only ones who saw improvements in market prospects were the emerging guinea pig farmers. Many of them had received help from international NGOs in improving and establishing production. The guinea pig farmers had formed cooperatives that now managed and negotiated sales independently. Simultaneously, for crop producers, the situation had become more uncertain. Some occasionally descended to sell their produce in the markets of Huancayo or Lima "to gain some coins." Others, including the milk producers, mostly depended on dominant agro-companies who paid low, non-negotiable prices. Many farmers felt that what they gained barely covered the costs of expensive fertilizers and pesticides. Moreover, since the liberalization of agricultural markets in Peru in the 1990s, the prices of many farming products have been pushed down. This has mostly benefitted large coastal farms (Valcárcel 2015) while in the highlands, with major number of smallholders, such policies have generated few advantages (Crabtree 2002).

Experiences of marginalization in the agricultural sector became clear in my interviews with farmers. Many felt that the state showed little interest in developing agriculture in the region. Smallholder Maximiliano Aguilar's opinion was that the governmental officials showed up only to make "pure promises" that they rarely fulfilled:
Sometimes they [the government officials] might appear here to present plans for some project...to build new water reservoirs or something else [to improve access to water]...Then they usually take their photos, as if to prove that yes... I went to visit the campesino, but afterwards you never see them again. (May 20, 2019)

The use of the term "peasant" (campesino) stems from the history of Peru's agrarian reform in 1969. During this time, the left-leaning military government changed the landownerships from large haciendas into worker-managed cooperatives through an expropriation process. With its goal of shifting from ethnic to class explanations of rural poverty, the reformist government began to use the term campesino for the beneficiaries of land tenure (Mayer 2009). Although most the highland population are of Indigenous origin, the state's policy that established new positive connotations for peasant identity while "Indigenous" became labelled as pejorative (Barrio de Mendoza and Damonte 2013). Moving into the neoliberal policy regime in the 2000s, the Andean region begun to appear in the state's rhetoric as "a backward obstacle to progress." Both Indigenous and peasant cosmologies have been called "primitive" and accused of standing in the way of modernity (Méndez 2011). The recent governmental downgrading of the highland peasants can thus help to explain why particularly farmers from the older generation associate feelings of marginalization with the highland campesino identity.

For many farmers, the poor prospects of highland farming with its multiple challenges had, however, become a reason to move to the cities in search of alternative livelihoods. Farming lands, especially in the lower valley, have been sold for construction purposes, needed by the expanding city of Huancayo. It was common to hear the farmers saying that "soon they will grow more cement than crops in this valley." Yet, as Altamirano (2014) argues, a new life in the city does not necessarily mean that highland farmers' vulnerabilities vanish. In the cities, highland migrants often face discrimination due to their ethnic or serrano backgrounds. For highland populations, moving away can also mean leaving behind something that transcends mere livelihood. In Andean societies, the land, the animals, nature, and the community have strong cultural values. For example, the term chacra that Andean people use for a field is not a simple expression for farming activities but a symbol around which life in the highlands orbits (Mayer 2002). In the Indigenous communities, farming still widely entails traditional customs such as offerings to the mountains and agricultural rituals and celebrations (Velásquez-Milla et al. 2011).

Although the smallholders who participated in this study identified themselves as peasants, many of these traditions were present in their lives. The ways people talked about 
farming, plants, animals, and mountains also echoed an intimate relationship with their living environment. When we discussed the current challenges, farmers commonly used expressions, such as "my little potato is suffering from the burning sun," or "we see our poor river dying from the droughts." Smallholders living in the upper Shullcas River basin reflected on environmental change through the glacier Huaytapallana, as smallholder Dario Paredes described:

It is sad to see the white snow peaks transforming slowly into lifeless black hills - and together with them vanishes our water. (May 21, 2019)

Although farmers close to the glacier were worried about losing their source of irrigation water, they also expressed melancholic feelings about the scenery without the white peaks. Gagné et al. (2014) discuss how in many highland societies, the glaciers do not only represent economic values but also have a crucial role as symbolic orientations. In a similar vein, Rasmussen (2016) depicts people's emotional connection to the glacier landscape in the Cordillera Blanca, Peru.

As I have shown here, for the smallholders' vulnerabilities are not simply a matter of disrupted livelihoods but can also have deep implications for the cultural aspects of their lives. Moreover, the vulnerabilities that the farmers experience take place within a specific socio-economic context that are besides climate change shaped by history, policies, and markets across multiple scales. Therefore, climate adaptation plans must also carefully consider the implications of such processes on place-specific vulnerabilities they aim to combat (Paerregaard 2018). In the next section, I discuss how Peru's climate adaptation policies (re)shape the vulnerabilities highland farmers' encounter.

\section{Peru's contradictory climate adaptation efforts}

Institutional structures across multiple scales have a central role in shaping people's susceptibility to climate risks and their adaptation (Agrawal 2010; Young and Lipton 2006). Here, I explore the institutional arrangements of Peru's climate adaptation, namely, how and by whom climate responses are defined, and how their articulation and implementation occur through "mosaic of interlayered scales," producing confusing outcomes of climate-related vulnerabilities (Nygren 2021:3).

Peru's climate adaptation is guided by the National Strategy on Climate Change (ENCC 2015), following the principles of the United Nations Framework Convention on Climate Change (UNFCCC). The formulation of the national adaptation policies is promising in terms of equity. The ENCC lists protecting the most vulnerable populations, including Amazonian and highland Indigenous and smallholder communities, as one of its priorities. The policies also recognize that climate-related vulnerabilities are linked to structural factors like inequalities and poverty. The means of tackling them include improving rural infrastructure, such as access to potable and irrigation water, the prevention of plant diseases, and fostering the competitiveness of national agri-products. The ENCC also highlights integrated participation, which is planned to be carried out as representation of diverse actors and sectors across society in policy formulation and implementation.

Yet the actors who participated in elaborating the ENCC mostly consist of powerful national and international institutions, such as the World Bank, most of Peru's ministries, and regional governments. The groups defined as "vulnerable" are only represented by three Amazonian Indigenous organizations and two organizations advocating Indigenous and peasant smallholder communities. The bottom-up approach is reflected in the ENCC's instrumental design merely in premises such as "capacitation," "awareness-raising," and technical assistance for those rendered vulnerable. Rural communities' own agency and means of adaptation receive little attention. The strategy mentions support for traditional farming practices but only in the case of officially recognized Indigenous communities. While this is important, the question of what constitutes Indigenous - especially in the Andean region - is complex. Diverse historical moments have shaped the reconstruction of Andean identity between Indigenous and peasant (Méndez 2011; Orlove 1993). Therefore, in the Andean context, identifying which farming practices are strictly Indigenous is not always straightforward. Moreover, both in the past and the present, Andean identity categories have mainly been defined through the state's lenses (Barrio de Mendoza and Damonte 2013). While underrepresentation of highland communities in the ENCC raises concerns, restricting climate support to state-defined farming categories can also have problematic adaptation outcomes.

According to Agrawal (2010), one of the key institutional functions in successful climate adaptation is how different levels of institutions connect in decision-making, particularly in resource allocation. However, in practice, such institutional categories and hierarchies are often much more fluid as diverse dominant actors pursue to drive particular interests across multiple layers of governance through "jumping of scales" (McCarthy 2005). 
Such institutional fluidity and dispersed hierarchies could be also observed in Peru's climate adaptation efforts. In the Mantaro River valley, the regional government of Junín (GORE Junín) has institutional responsibility for regional climate governance. The GORE Junín adaptation plan (ERCC), published in $2014,{ }^{2}$ outlines its goals as "improving the adaptive capacities and resilience of farmers and livestock producers facing climate change, through incorporation of appropriate agro-technologies and good practices of adaptation across the department" (ERCC 2014: 66). GORE Junín also promises to promote conservation of water resources and technical assistance and consultation for communities threatened by climatic risks (POI 2019). The ENCC for their part states that the central government commits to financially supporting such region-specific adaptation practices by providing an annual budget for each regional government (ENCC 2015).

However, the regional government's project budget allocation shows some discords in such articulations and intentions. In the inversion plan for 2020-2022 (PMI 2020-2022), the budget was assigned to 190 different projects, of which only seven are related to agriculture and six to environmental conservation or climate adaptation. A notable share of the budget is allocated to diverse construction projects, such as roads and bridges. An official from the subdepartment of environmental management at GORE Junín told me in an interview that weak adaptation practices were due to limited funding from the central government. There had been some adaptation initiatives, such as reforestation projects, but these had largely failed due to a shortage of economic and human resources to maintain them. This was confirmed by an official from GORE Junín's sub-department of agriculture:

We see all the farmers' urgent needs in our daily work, but how are you supposed to help them if you do not even have an appropriate car to reach the rural districts? Our governors place little importance on agriculture. The budget comes from the central government, and it is very limited. (June 6, 2019)

At the national level, in MINAGRI or MINAM for example, state officials portrayed the adaptation failure as a consequence of inefficiency, lack of professionality, or corruption in regional and local institutions. Meanwhile, regional officials working in climate issues alongside GORE Junín felt that many adaptation projects, such as building new water reservoirs, were mostly political games played between high-level authorities and powerful private actors rather

\footnotetext{
2 Since approbation of La ley Orgánica de Gobiernos Regionales in 2002, regional climate adaptation strategies have become an obligation for regional governments in Peru.
}

than attempts to reduce vulnerabilities. As a regional water management official told:

[C] urrently in Peru, contract systems do not work to provide benefits for the respective people, but rather for the company owners... I mean, the companies arrive, they make their offer, it gets accepted and they execute their project. Often the projects fail to work in that context for diverse reasons. However, both sides who signed the contract are still content at the end of the day. In other words, as we say here, me llevo toda la plata y no pasó nada - As long as I get my money, everything will be fine. (March 8, 2019)

Other officials working in partnership with regional adaptation mentioned that economic interests made the regional governors to prioritize projects other than climate adaptation. I was told that to build different kinds of infrastructure was more expensive than for instance water reservoirs. In other words, in the case of first mentioned, "there were more shares to divide between different interest groups." In one of the interviews, a regional state official said that he felt that they had no option but to participate in such arrangements, whether they wanted to or not:

[I]n these positions, we must act in certain kinds of frameworks that are set from above. I mean, this is allowed and this is not, and you know the consequences if you break these conditions. If I want to keep my job I must act accordingly. If I tried to orchestrate things differently, the first thing the highest echelon would do is to kick me out of this position - or at least send me to another region. (March 10, 2019)

The administration of economic resource between and within diverse institutions is outside the scope of this study. However, the inconsistency between the statements of national adaptation policy and what the interviews with diverse officials revealed illustrates some serious institutional disruptions. Institutional partnership across multiple spaces of governance is considered as one of the corner stones of successful adaptation (Ivey et al. 2004). Considering GORE Junín's difficulties in targeting the resources to climate adaptation and the conflicting relations between different governmental authorities, this seemed not to be the case. These contradictions also raise questions on whether the design of national adaptation policies corresponds with regional institutional realities. Moreover, this illustrates that political scales are often not fixed to certain institutional levels and firm hierarchical relations between them. Rather, scales emerge as products of blurry and transversal relations between transnational organizations, private companies, different governmental actors, and diverse groups of local people (Sud 2017). 
Such overlapping scalar configurations were also embedded in the discursive dimensions of climate adaptation. Peru's climate adaptation policies' technocratic discourse adapted from the international development organizations were often echoed in interviews with the regional and local authorities. They considered that adaptation efforts also failed due to the famers' "unconsciousness" and ignorant attitudes. In their view, farmers needed environmental capacitation to get them to abandon inefficient farming practices like "outdated" canal irrigation. While such discourses undermine smallholders' agency to determine their own adaptation needs, they also mask the structural causes of vulnerabilities (Paerregaard 2018). Some farmers, for instance, considered that climate change was a result of local people using too many plastic items, throwing trash in the rivers, and not recycling their waste. They often shouldered the responsibility for adaptation on themselves, remarking, "we must stop contaminating our rivers" or "we must learn to recycle." This reflects how dominant climate discourses across multilayered governance can translate into deeply misleading local vulnerability perceptions (Yates 2012). Moreover, it depicts how vulnerabilities are mutually (re) produced through intersecting scalar power dynamics (Sayre 2015). While local people "adapt" the dominant climate discourse and practices, they are simultaneously active actors in contesting and shaping the prevailing scalar power relations, as I will discuss in the following section.

\section{Uneven power dynamics beyond climate policies}

Besides unevenly distributed power in climate decisionmaking, vulnerabilities can also be created through marginalizing policies beyond adaptation (O'Brien et al. 2008). Here, I examine on one hand how the smallholders' vulnerabilities to climate change are (re)shaped by power imbalances in the wider field of agricultural, economic, and water policies. On the other hand, I discuss how the farmers also become engaged in these multi-scalar power dynamics as active agents, while seeking for ways to create their own means of adaptation.

As part of Peru's neoliberal economic reforms in the 1990s, President Alberto Fujimori signed a free trade agreement with the World Trade Organization (WTO) in 1994. This included a considerable reduction in tariffs for agricultural products. The government argued that more open agricultural trade would bring prosperity, economic growth, and poverty reduction for the whole country. While such policies boosted the economy, the benefits have not been equally distributed. Large-scale, export-oriented coastal agriculture has expanded, while rural highland regions have seen few improvements, and inequalities and poverty have merely increased (Valcárcel 2015). This gap has further deepened with large-scale farmers profiting most from the governments' irrigation infrastructure and other technological investments (Hendriks and Boelens 2016). Yet, in the recent trade policy review of Peru, WTO congratulated the country for its successful policies in the past decade — particularly reductions in import tariffs. In 2019 Peru's MFN tariff was $2.2 \%$, which is one of the lowest import tariffs among WTO member countries (WTO 2019). This means that Peruvian producers are the least protected in increasingly competitive and globalized agricultural markets.

In recent years, small-scale farmers have organized several nation-wide strikes to address the government's disproportionate agri-policies. In January 2018, farmers took to the streets demanding an end to imported potato subsidies that were reducing national potato prices. This particularly affected farmers in the highlands where the bulk of potatoes are grown. The authorities, however, claimed that the price drop was caused by the farmers' own potato overproduction. As no policy changes were made, the following year, in May 2019, the farmers arranged another protest. When I discussed with protesting farmers in Plaza Huamanmarca in Huancayo at the time, they told me that they had had enough of agri-policies that discriminated national small producers. Later that month, MINAGRI organized a roundtable to address the current challenges in Peru's agricultural sector. However, this initiative has been criticized for underrepresentation of smallholder organizations and weak discussion of the structural issues behind the farmers' grievances (Eguren 2019).

Moreover, disagreements over water distribution were escalating tensions between the authorities and the farmers. In the Mantaro River valley, smallholders increasingly had to compete with industries, urban populations, and even with each other, over diminishing water resources. This pressure often erupted as fierce debates in the local water management meetings. The farmers' discontent concerned mainly government's water policies. They for instance claimed that the increased water tariffs for irrigation infrastructure maintenance and new motorized irrigation systems they promoted did not correspond to their economic realities. As smallholder Cristóbal Quilla stated as he stood up to express his frustration in the workshop on "Capacitation of Cunas River water users":

So are we going to pay for the rain too? You should understand that the farmer does not have the capacity to pay for the water tariff. Even less with all these climatic events...frosts...droughts. There is just no sense in this. (May 18, 2019)

The new water practices like the water tariff draw on the governmental agendas on modern and efficient water use, guided by international development agencies such as 
the World Bank (Roa-García et al. 2015). Moreover, while Peru's climate policies emphasize integrated participation, in the local water meetings, this was carried out as water authorities presenting predetermined technical plans to farmers. Often, the farmers had not heard about the plans before and had difficulty understanding their technical language. Similar "disencounters" between farmers and the authorities have also been documented in other locations of the Peruvian Highlands (Stensrud 2019).

The practices in the fields of agricultural, economic, and water policies show how highland farmers' vulnerabilities are not only a matter of climate policies, or how power is exercised in climate governance. The pre-conditions of the smallholders' vulnerabilities are rooted to "invisibility" of their concerns in the political agendas beyond climate adaptation (Lukes 2005). Peru's economic and agricultural policies have created market structures that make smallproducers access to them increasingly difficult. Meanwhile, the smallholders' claims are systematically bypassed and precluded by placing the blame of their grievances to selfresponsibilization. In similar vein, while water stands as central for climate adaptation, the governmental water officials seek to plant universal water policies amidst the smallholder communities while dismissing the farmers' concerns for their adverse outcomes in the context of rural highlands.

In the absence of consensus with the authorities, the smallholders were looking for other ways to solve their increasing irrigation water needs. One method was to create "up-scaled alliances" with societally influential actors (Hoogesteger and Verzijl 2015). The case of Yanacocha water reservoir in the Cunas River basin is illustrative in that sense. The project was originally initiated by the National Water Authority (ANA) and MINAGRI to improve irrigation in the lower Cunas Basin. However, as the reservoir would generate irrigation benefits only for some farmers, it had created a widespread conflict. The leading figure of the Yanacocha opposition was the director of a local potable water service company (SEDAM). He was gradually joined by several communities in the upper Cunas and regional congress representatives. In an interview, the SEDAM director told me that their resistance stemmed from a concern of the environmental damage that reservoir construction would cause. He also drew me a map to illustrate another potential place for a reservoir in the upper basin. On his opinion, this proposal for a reservoir would be a better investment than Yanacocha as it would provide wider irrigation benefits for the entire basin.

These claims were however rejected by communities in the lower basin - supported by the Cunas irrigation organization, the Local Water Authority (ALA), and other congress members. They stated that the oppositional group was sabotaging their water needs for "egoistic reasons." The inflamed relations between the two allies were also visible in the "pro-Yanacocha" meetings, in which they refused to invite members of the oppositional communities. In one such meeting that I attended, a congress representative of Junín was invited to boost the Yanacocha project forward, as the president of one of the smallholder communities, Victor Quinto stated:

Many say that this project [Yanacocha] will not realize (no va ir). But now it is time that our project will be considered at national level. This is a historical day for us. This project will help us to combat the increasing water stress that we are facing in the pampas of lower Cunas. (March 30, 2019)

While the congress representative rhetorically replied in his concluding statement:

Few persons stand to speak for the small-scale farmers. But we all know that without water there will be no agriculture. Without water, we will never be able to export our products abroad. But now it is time to fight (pelear) for this [project] to convert into a law. And I will personally commit in debating and fighting with all the persons who think otherwise. (March 30, 2019)

The case of the Yanacocha reservoir stands as an illustrative example for the complex, nuanced and intersecting power dynamics within and beyond the scales of official climate adaptation. While the reservoir began as high water authorities' plan to tackle water scarcities, it soon evolved into a deeply contested ground over conflicting economic, political, and water claims. However, the struggle over Yanaconcha cannot be fit into simple dichotomies between the actors or a fixed scale (Sayre 2015). Rather, the conflict was an outcome of fluidity of crosscutting concerns, articulations, and ambitions across multiple scales: smallholders' grievances over their livelihoods, congress members' political projects, SEDAM's overlapping water agendas, and governmental officials fulfilling state policy strategies. All of these claims are shaped by multi-scalar processes of policies, economy, and climate change beyond and within the place, the Cunas River basin, where they become manifested. While the smallholder farmers actively participated in contesting and shaping the prevailing scalar power relations, the vulnerability outcomes remain differentiated and uneven. The tensions around Yanacocha had so far halted any attempts to improve farmers' water access, and in any of the presented options part of them would be left faced with deepening water- and climate-related vulnerabilities. Climate adaptation efforts to reduce vulnerabilities of marginalized groups might have well-intentioned ambitions, like in the case of Yanacocha water reservoir. However, without considering the multi-scalar power imbalances in the wider fields of policy and how these alter place-specific socio-political characteristics, they risk (re)producing 
vulnerabilities to climate change - rather than alleviating them.

\section{Conclusion}

This article has examined interrelations between the multiscalar power dynamics in climate adaptation and the (re) production of smallholder farmers' vulnerabilities in the Mantaro River valley, Peru. The study paid special attention to how socio-political processes across multiple scales shape local vulnerability experiences and adaptation outcomes through differentiated access to resources, markets, and political representation (Faye and Ribot 2017). Such a multidimensional approach to vulnerability contributes to a better understanding of the ways power and politics at multiple scales shape vulnerabilities and adaptation under climate change (Nightingale 2017; Taylor 2015).

Climate extremes such as droughts and frosts present new challenges to smallholder livelihoods in the Peruvian highlands. However, as this study shows, smallholders' vulnerabilities are not only a simple result of changing climate. Instead, they are deeply entangled with, and shaped by, restricted access to resources and disproportionate policies that have debilitated their opportunities for adaptation. Moreover, unequal market access influenced by multiple spaces of governance (re)construct smallholders' exposure to climate risks in highly differentiated ways. While these pose a serious risk for smallholders' livelihoods, the vulnerabilities in the Andean context can also have deep socioecological and cultural implications.

At first glance, the official climate adaptation policies of Peru are promising in terms of protecting the most marginalized populations facing climate risks. However, highland farmers remain weakly represented in climate decision-making processes. Rather, the adaptation strategies draw on technocratic mainstream vulnerability and adaptation premises defined by powerful national and international institutions. These mostly promote "capacitation," "awareness-rising," and technical assistance for those rendered vulnerable, ignoring the rich agricultural knowledge the highland farmers have traditionally used for adaptation. Projects of infrastructural development and technical assistance mostly benefit the larger, export-oriented coastal farms, while the adaptation policies have merely deprived highland smallholders' access to productive resources and debilitated their own means of adaptation. Moreover, implementation of climate adaptation policy in the Mantaro River valley remains weak due to contradicting relations and transversal agendas between diverse institutions and actors across multiple scales.
Smallholders' vulnerabilities are also shaped by power imbalances in the wider field of agricultural, economic, and water policies. These policies contradict with Peru's climate adaptation that claims to strengthen national agricultural production and inclusive representation. Instead, the smallholders had limited space to influence the decision-making, and current agri and water policies were rather weakening their farming and market opportunities through "invisibilizing" their claims from political agendas (Lukes 2005). Under intensifying competition for resources, market pressures, and climatic challenges, many farmers were seeking for ways to adapt by allying with influential actors. However, while this allowed smallholders to influence the prevailing scalar power configurations, the associated conflicts merely deepened divisions and tensions among farmers resulting in differentiated vulnerability outcomes. This depicts how vulnerabilities related to climate change are (re)produced and contested through intersecting and cross-cutting scalar dynamics, rather than being a simple matter of a specific geographical scale or linear "levels" of governance (Sayre 2015).

Overall, the study shows that the (re)production of vulnerabilities in the Peruvian Highlands has more to do with larger socio-political structures in which protection of the most marginalized populations is not prioritized. In order to mitigate vulnerabilities in a more equitable manner, it is fundamental to consider how people perceive changes - climatic or otherwise - in the place they live, and how these experiences are mutually shaped by multi-scalar power relations and contextspecific socio-political processes. This study has provided empirical insights into highland smallholders' vulnerabilities in Peru. Moreover, it contributes to analytical understanding of the political ecology of vulnerability on the interface of power relations and relational scalar dynamics in producing vulnerabilities that resonate with other marginalized rural populations faced with climate change.

Acknowledgements I am deeply thankful to the smallholders of the Mantaro River valley for providing their valuable time to this study. I also appreciate the cooperation of the many government institutions in Peru. This paper has benefitted greatly from intriguing discussions with Anja Nygren and Eija Ranta as well as other colleagues at the University of Helsinki. I am grateful to the two anonymous reviewers for their highly valuable and constructive comments that helped to improve the earlier versions of the manuscript. Thank you, Marie-Louise Karttunen for language correction and Noora Rämö for drawing the map.

Funding Open access funding provided by University of Helsinki including Helsinki University Central Hospital. This research is funded by the Kone Foundation (grant no. 4705967).

Open Access This article is licensed under a Creative Commons Attribution 4.0 International License, which permits use, sharing, adaptation, distribution and reproduction in any medium or format, as long as you give appropriate credit to the original author(s) and the source, provide a link to the Creative Commons licence, and indicate if changes were made. The images or other third party material in this article are 
included in the article's Creative Commons licence, unless indicated otherwise in a credit line to the material. If material is not included in the article's Creative Commons licence and your intended use is not permitted by statutory regulation or exceeds the permitted use, you will need to obtain permission directly from the copyright holder. To view a copy of this licence, visit http://creativecommons.org/licenses/by/4.0/.

\section{References}

Agrawal A (2010) Local institutions and adaptation to climate change. In: Mearns R, Norton A (eds) Social dimensions of climate change: equity and vulnerability in warming world. The World Bank, Washington, DC, pp 173-198

Altamirano T (2014) Refugiados ambientales: Cambio climático y migración forzada. Fondo Editorial de la Pontificia Universidad Católica del Perú, Lima

ANA (2010) Estudio de factibilidad del proyecto "Mejoramiento y regulación del sistema de riego de la cuenca media y baja del río Cunas.” Gobierno Regional Junín-Autoridad Nacional del Agua, Lima

Anderson EP, Marengo J, Villaba R, Halloy S, Young B et al (2011) Consequences of climate change for ecosystems and ecosystem services in the tropical Andes. In: Herzog SK, Martínez R, Jorgensen PM, Tiessen $\mathrm{H}$ (eds) Climate Change and Biodiversity in the tropical Andes. Inter-American Institute for Global Change Research and Scientific Committee on Problems of the Environment, San Jose dos Campos and Paris

Artur L, Hilhorst D (2012) Everyday realities of climate change adaptation in Mozambique. Glob Environ Chang 22:529-536. https:// doi.org/10.1016/j.gloenvcha.2011.11.013

Barrio de Mendoza R, Damonte G (2013) Los dilemas del Estado peruano en la implementación y aplicación de la Ley de Consulta Previa en los Andes peruanos. Anthropologica 31:127-147

Basset TJ, Fogelman C (2013) Déjà vu or something new? The adaptation concept in the climate change literature. Geoforum 48:42-53. https://doi.org/10.1016/j.geoforum.2013.04.010

Bury J, Mark BG, McKenzie JM, French A, Baraer M et al (2011) Glacier recession and human vulnerability in the Yanamarey watershed in the Cordillera Blanca, Peru. Clim Change 105:179-206. https://doi.org/10.1007/s10584-010-9870-1

CIIFEN (2018) Entendiendo clima de la Cuenca del Río Mantaro, Perú. Centro Internacional para la investigación del Fenómeno de El Niño, Guayaquil

CONVEAGRO (2018) Junín: Heladas dañan más de 40 mil hectáreas de cultivos. Convención Nacional del Agro Peruano. https://conve agro.org.pe/junin-heladas-danan-mas-de-40-mil-hectareas-decultivos/. Accessed 14 Feb 2020

Correo D (2017) Agua será compartida con regantes hasta el mes de noviembre. https://diariocorreo.pe/edicion/huancayo/agua-seracompartida-con-regantes-hasta-el-mes-de-noviembre-763105/. Accessed 8 Oct 2018

Crabtree J (2002) The impact of neo-liberal economics on Peruvian peasant agriculture in the 1990s. J Peasant Stud 29:131-161. https://doi.org/10.1080/03066150412331311049

DRA Junín (2019) Síntesis agrario - Agosto 2019. Dirección de Estadística e Información Agraria, Dirección Regional de Agricultura Junín

Drenkhan F, Carey M, Huggel C, Seidel J, Oré MT (2015) The changing water cycle: climatic and socioeconomic drivers of waterrelated changes in the Andes of Peru. WIRESs Water 2:715-733. https://doi.org/10.1002/wat2.1105

Eguren F (2019) En el Perú solo hay política agraria para los grandes agroexportadores. Ser.pe. Published on: 8.5.2019. http://www. noticiasser.pe/entrevista/ferna ndo-eguren-en-el-peru-solo-hay-politica-agraria-para-los-grand es-agroexportadores. Accessed 15 Jan 2020

ENCC (2015) Estrategia Nacional ante el Cambio Climático. Ministerio del Ambiente, Lima

ERCC (2014) Estrategia Regional de Cambio Climático de Junín. Gobierno Regional de Junín, Huancayo

Eriksen S, Nightingale A, Eakin H (2015) Reframing adaptation: the political nature of climate change adaptation. Glob Environ Chang 35:523-533. https://doi.org/10.1016/j.gloenvcha.2015.09.014

Faye P, Ribot J (2017) Causes for adaptation: access to forests, markets and representation in Eastern Senegal. Sustainability 9:311. https://doi.org/10.3390/su9020311

Gagné K, Rasmussen M, Orlove B (2014) Glaciers and society: attributions, perceptions, and valuations. Wires Clim Change 5:793-808. https://doi.org/10.1002/wcc.315

Goldman MJ, Turner MD, Daly M (2018) A critical political ecology of human dimensions of climate change: epistemology, ontology and ethics. Wires Clim Change 9(4):e526. https://doi.org/ $10.1002 /$ wcc. 526

Hendriks J, Boelens R (2016) Acumulación de derechos de agua en el Perú. Antropologica 37:13-32. https://doi.org/10.18800/anthr opologica.201602.001

Holler J (2014) Adaptation policy and adaptation realities: local social organization and cross-scale networks for climate adaptation on Mount Kilimanjaro. GeoJournal 79:737-753. https:// doi.org/10.1007/s10708-014-9549-7

Hoogesteger J, Verzijl A (2015) Grassroots scalar politics: insights from peasant water struggles in the Ecuadorian and Peruvian Andes. Geoforum 62:13-23. https://doi.org/10.1016/j.geofo rum.2015.03.013

IGP (2012) Manejo de riesgos de desastres ante eventos meteorológicos extremos en el valle del Mantaro. Instituto Geofísico del Perú, Lima

INAIGEM (2017) Informe de la Situación de los Glaciares y Ecosistemas de Montaña en el Perú. Instituto Nacional de Investigación en Glaciares y Ecosistemas de Montaña, Dirección de Información y Gestión del Conocimiento, Lima

INEI (2019) PERÚ: Evaluación de los Indicadores de Empleo e Ingreso por Departamento, 2007-2018. Instituto Nacional de Estadística e Informática, Lima

IPCC (2014) Climate change 2014: impacts, adaptation, and vulnerability. Part A: Global and sectoral aspects. Contribution of Working Group II to the Fifth Assessment Report of the Intergovernmental Panel on Climate Change. Field CB, Barros VR, Dokken DJ, Mach KJ, Mastrandea MD, Bilir TE, Chatterjee M, Ebi KL, Estrada YO, genova RC, Girma B, Kissel ES, Levy AN, MacCrecken S, Mastrandea PR, Whote LL (eds), Cambridge University Press, Cambridge, United Kingdom and New York

Ivey JL, Smithers J, De Loë RC, Kreutzwiser RD (2004) Community capacity for adaptation to climate-induced water shortages: linking institutional complexity and local actors. Environ Manage 33:23-47. https://doi.org/10.1007/s00267-003-0014-5

Lennox E, Gowdy J (2014) Ecosystem governance in a highland village in Peru: facing the challenges of globalization and climate change. Ecosyst Serv 10:155-163. https://doi.org/10.1016/j. ecoser.2014.08.007

Lennox E (2015) Double exposure to climate change and globalization in a Peruvian highland community. Soc Nat Resour 28:781796. https://doi.org/10.1080/08941920.2015.1024364

Lukes S (2005) Power: a radical view. Palgrave Macmillan, Basingstoke

Lynch B (2012) Vulnerabilities, competition and rights in the context of climate change toward equitable water governance in Peru's Rio Santa Valley. Glob Environ Chang 22:364-373. https://doi. org/10.1016/j.gloenvcha.2012.02.002 
Lynch B (2018) Water and power in the Peruvian Andes. In: Seligmann LJ, Fine-Dare KS (eds) The Andean World. Routledge, London and New York

MacKinnon D (2011) Reconstructing scale: towards a new scalar politics. Prog Hum Geogr 35:21-36. https://doi.org/10.1177/03091 32510367841

Marino E, Ribot J (2012) Special issue Introduction: Adding insult to injury: climate change and the inequities of climate intervention. Glob Environ Chang 2:323-328. https://doi.org/10.1016/j.gloen vcha.2012.03.001

Mark BG, French A, Baraer M, Carey M, Bury J et al (2017) Glacier loss and hydro-social risks in the Peruvian Andes. Global Planet Change 159:61-76. https://doi.org/10.1016/j.gloplacha.2017.10. 003

Mayer E (2002) The articulated peasants: household economies in the Andes. Routledge, New York

McCarthy J (2005) Scale, sovereignity, and strategy in environmental governance. Antipode 37:731-753. https://doi.org/10.1111/j. 0066-4812.2005.00523.x

McDowell JZ, Hess JJ (2012) Accessing adaptation: multiple stressors on livelihoods in the Bolivian highlands under a changing climate. Glob Environ Chang 22:342-352. https://doi.org/10. 1016/j.gloenvcha.2011.11.002

Méndez CG (2011) De indio a serrano: nociones de raza y geografía en el Perú (siglos XVIII-XXI). Histórica 1:53-102

MINAGRI (2018) Anuario Estadístico de Producción Agrícola 2017. Ministerio de Agricultura y Riego, Lima

Montaña E, Diaz PH, Hurlbert M (2016) Development, local livelihoods, and vulnerabilities to global environmental change in the South American Dry Andes. Reg Environ Change 16:22152228. https://doi.org/10.1007/s10113-015-0888-9

Moore A (2008) Rethinking scale as a geographical category from analysis to practice. Prog Hum Geogr 32:203-25. https://doi. org/10.1177/2F0309132507087647

Nagoda S, Nightingale AJ (2017) Participation and power in climate change adaptation policies: vulnerability in food security programs in Nepal. World Dev 100:85-93. https://doi.org/10. 1016/j.worlddev.2017.07.022

Neumann PR (2009) Political ecology: theorizing scale. Prog Hum Geogr 33:398-406

Nightingale A (2017) Power and politics in climate change adaptation efforts: struggles over authority and recognition in the context of political instability. Geoforum 84:11-20. https://doi. org/10.1016/j.geoforum.2017.05.011

Nygren A (2021) Water and power, water's power: state-making and socionature shaping volatile rivers and riverine people in Mexico. World Dev 146:105615. https://doi.org/10.1016/j.world dev.2021.105615

O’Brien K, Leichenko R, Kelkar U, Venema H, Aandahl G et al (2008) Mapping vulnerability to multiple stressors: climate change and globalization in India. Glob Environ Chang 14:303-313

Orlove B (1993) Putting race in its place: order in colonial and postcolonial Peruvian geography. Soc Res 60:301-336

Orlove B, Taddel R, Podestá G, Borad K (2011) Environmental citizenship in Latin America: climate, intermediate organizations and political subjects. Lat Am Rev 46:115-140

Paerregaard K (2017) Power in/of/as water: revisiting the hydrologic cycle in the Peruvian Andes. Wires Water 5(12):e1270. https:// doi.org/10.1002/wat2.1270

Paerregaard, (2018) The climate-development nexus: using climate voices to prepare adaptation initiatives in the Peruvian Andes. Climate Dev 10:360-368. https://doi.org/10.1080/17565529.2017. 1291400

Perez C, Nicklin C, Dangles O, Vanek S, Sherwood S et al (2010) Climate change in the high Andes: implications and adaptation strategies for small-scale farmers. Int J Environ Cult Econ Soc Sustain 6:71-88

Perreault T (2020) Climate change and climate politics: parsing the causes and effects of the drying of Lake Poopó, Bolivia. J Lat Am Geogr 19:26-46. https://doi.org/10.1353/lag.2020.0070

POI (2019) Plan Operativo Institucional Multianual 2020-2022. Gobierno Regional Junín, Huancayo

PMI (2020-2022) OPMI del Gobierno Regional Junín 2020-2022. Gobierno Regional Junín, Huancayo

Rabatel A, Francou B, Soruco A, Gomez J, Cáceres B et al (2013) Current state of glaciers in the tropical Andes: a multi-century perspective on glacier evolution and climate change. Cryosphere 7:81-102. https://doi.org/10.5194/tc-7-81-2013

Rasmussen MB (2016) Unsettling times: living with the changing horizons of the Peruvian Andes. Lat Am Perspect 4:73-86. https://doi. org/10.1177/2F0094582X16637867

Rhoades RE, Ríos XZ, Ochoa JA (2008) Mama Cotacachi: history, local perceptions, and social impacts of climate change and glacier retreat in the Ecuadorian Andes. In: Orlove B, Wiegandt E, Luckman BH (eds) Darkening peaks: glacier retreat, science and society. University of California Press, Berkley

Ribot J (2010) Vulnerability does not fall from the sky: toward multiscale pro-poor climate policy. In: Mearns R, Norton A (eds) Social dimensions of climate change: equity and vulnerability in warming world. The World Bank, Washington, DC

Ribot J (2011) Vulnerability before adaptation: toward transformative climate action. Glob Environ Chang 21:1160-1162. https://doi. org/10.1016/j.gloenvcha.2011.07.008

Ribot J (2014) Cause and response: vulnerability and climate in the Anthropocene. J Peasant Stud 41:667-705. https://doi.org/10. 1080/03066150.2014.894911

Roa-García MC, Urteaga-Crovetto P, Bustamante-Zenteno R (2015) Water laws in the Andes: a promising precedent for challenging neoliberalism. Geoforum 64:270-280. https://doi.org/10.1016/j. geoforum.2013.12.002

RPP (2018) Huancayo: productores de papa acordaron acatar paro regional. https://rpp.pe/peru/junin/huancayo-productores-de-papaacordaron-acatar-paro-regional-noticia-1102177. Accessed 8 Jan 2019

Sayre NF (2015) Scales and polities. In: Perreault T, Bridge G, McCarthy J (eds) The Routledge handbook of political ecology. Routledge, London

Sietz D (2014) Regionalisation of global insights into dryland vulnerability: better reflecting smallholders' vulnerability in Northeast Brazil. Glob Environ Chang 25:173-185. https://doi.org/10. 1016/j.gloenvcha.2014.01.010

Stensrud AB (2019) "You cannot contradict the engineer": discounters of modern technology, climate change, and power in the Peruvian Andes. Crit Anthropol 4:420-438. https://doi.org/10.1177/2F030 $8275 \times 18821164$

Sud N (2017) State, scale and networks in the liberalization of India's land. Environ Plann C Polit Space 35:76-93. https://doi.org/10. 1177/2F0263774X16655801

Swyngedouw E (2004) Globalisation or 'glocalisation'? Networks, territories and rescaling. Camb Rev Int Aff 17:25-48. https://doi.org/ $10.1080 / 0955757042000203632$

Taylor M (2013) Climate change, relational vulnerability and human security: rethinking sustainable adaptation in agrarian environments. Clim Dev 5:318-327. https://doi.org/10.1080/17565529. 2013.830954

Taylor M (2015) The political ecology of climate change adaptation: livelihoods, agrarian change and the conflicts of development. Routledge, London and New York

Trasmonte G, Chavez R, Segura B, Rosales JL (2008) Frost risks in the Mantaro River Basin. Adv Geosci 14:265-270 
Turner M (2016) Climate vulnerability as a relational concept. Geoforum 68:29-38. https://doi.org/10.1016/j.geoforum.2015.11.006

Valcárcel M (2015) Perú: Una mirada actual al mundo rural. Fondo Editorial de la Pontificia Universidad Católica del Perú, Lima

Velásquez-Milla D, Casas A, Torres-Guevara J, Cruz-Soriano A (2011) Ecological and socio-cultural factors influencing in situ conservation of crop diversity by traditional Andean households in Peru. J Etnobiol Etnomed 7:40

Vergara W, Deeb A, Leino I, Kitoh A, Escobar M (2011) Assessment of the impacts of climate change on mountain hydrology: development of a methodology through a case study in the Andes of Peru. The International Bank for Reconstruction and Development/World Bank, Washington

Vuille M, Carey M, Huggel C, Buytaert W, Rabatel A et al (2018) Rapid decline of snow and ice in the tropical Andes - impacts, uncertainties and challenges ahead. Earth Sci Rev 176:195-213. https://doi.org/10.1016/j.earscirev.2017.09.019

Walsh-Dilley M (2020) Resilience compromised: producing vulnerability to climate and market among quinoa producers in Southwestern Bolivia. Glob Environ Chang 65:102165. https://doi.org/ 10.1016/j.gloenvcha.2020.102165

Wongchuig CS, Mello CR, Chou SC (2018) Projections of the impacts of climate change on the water deficit and precipitation erosive indexes in Mantaro River Basin. J Mt Sci 15:264-279. https://doi. org/10.1007/s11629-017-4418-8
WTO (2019) Trade policy review: Peru. The Fifth Trade Policy Review of Peru, WTO

Yates JS (2012) Uneven interventions and the scalar politics of governing livelihood adaptation in rural Nepal. Glob Environ Chang 22:537-546. https://doi.org/10.1016/j.gloenvcha.2012.01.007

Yates JS (2014) Power and politics in the governance of communitybased adaptation. In: Ensor J, Berger R, Huq S (eds) Communitybased adaptation to climate change: emerging lessons. Practical Action Publishing, Rugby UK, pp 15-34

Young KR, Lipton JK (2006) Adaptive governance and climate change in the tropical highlands of western South America. Clim Change 78:63-102

Zimmerer KS (1991) Managing diversity in potato and maize fields of the Peruvian Andes. J Etnobiol 11:23-49

Zimmerer KS, Jones AD, De Haan S, Creed-Kanashiro H, Carrasco M et al (2018) Climate change and food: challenges and opportunities in tropical mountains and agrobiodiversity hotspots, vol 12. ReVista: Harvard Review of Latin America, Cambridge, pp 53-57

Publisher's note Springer Nature remains neutral with regard to jurisdictional claims in published maps and institutional affiliations. 